\title{
АСИМЕТРІЇ ФІНАНСУВАННЯ ВИДАТКІВ МІСЦЕВИХ БЮДЖЕТІВ НА СОЦІАЛЬНИЙ ЗАХИСТ ТА СОЦІАЛЬНЕ ЗАБЕЗПЕЧЕННЯ
}

Бюджетне фінансування сочіального захисту та сочіального забезпечення є одним з важливих чинників суспільного розвитку, який визначає рівень життя населення ци добробут найменш забезпечених його верств. Провідна роль місиевих бюджетів України у реалізації сочіальної функції держави обумовлена підвищенням ефективності процесу надання суспільних послуг завдяки наближеності до їх безпосереднього споживача. Цей процес базується на приниипі субсидіарності, потребує достатнього рівня фінансової забезпеченості органів місчевого самоврядування $і$ демонструє основну ідею концепції бюджетної децентралізації. У статті проаналізовано чинну практику фінансування місчевими бюджетами Украӥни заходів на соціальний захист та соціальне забезпечення населення з метою визначення його ефективності в умовах обмежених бюджетних ресурсів держави $i$ необхідності забезпечення сочіальних гарантій для громадян. Проведено групування країн-членів СС за пріоритетністю видатків на соціальний захист населення, зроблено порівняння з відповідними показниками в Україні. Розраховано частку видатків на сочіальний захист та сочіальне забезпечення зведеного бюджету у ВВП України. Визначено роль видатків на соціальний захист та сочіальне забезпечення у видатковій частині місцевих бюджетів Украйни, розглянуто їхню структуру. Доведено, щзо фінансування сочіальних видатків має хаотичний характер; будь-які сталі тенденції щзодо динаміки питомої ваги окремих складових сочіальних видатків відсутні. Зважаючи на проведення в Украӥні реформи бюджетної децентралізації, досліджено розмежування бюджетного фінансування соціального захисту у розрізі державного та місцевих бюджетів. Визначено, щзо частка видатків на соціальний захист та сочіальне забезпечення в структурі місцевих бюджетів Украйни є високою, разом з тим, на практищі це не завжди забезпечує належний рівень якості надання сочіальних послуг населенню. Обтрунтовано потребу у розробленні комплексного підходу до реформування бюджетного механізму реалізації соціальної функиії держави на принципах стабільності, прозорості та виваженого паритету інтересів держави і суспільства.

Ключові слова: сочіальна політика, бюджетне фінансування, місцеві бюджети, сочіальні видатки, соціальний захист, соціальне забезпечення.

Л.П. СИДЕЛЬНИКОВА

Херсонский национальный технический университет ORCID: 0000-0001-7182-2923

\section{АСИМЕТРИИ ФИНАНСИРОВАНИЯ РАСХОДОВ МЕСТНЫХ БЮДЖЕТОВ НА СОЩИАЛЬНУЮ ЗАЩИТУ И СОЦИАЛЬНОЕ ОБЕСПЕЧЕНИЕ}

Бюджетное финансирование соииальной защчить и соџиального обеспечения является одним из важных факторов общественного развития, определяющим уровень жизни населения и благополучие наименее обеспеченных его слоев. Ведущая роль местных бюджетов в реализачии сочиальной функции государства обусловлена повышением эффективности прочесса предоставления общественных услуг благодаря приближенности ких непосредственному потребителю. Этот процесс базируется на принципе субсидиарности, нуждается в достаточном уровне финансовой обеспеченности органов местного самоуправления и демонстрирует основную идею концепциии бюджетной децентрализации. В статье проанализирована действующая практика финансирования местными бюджетами Украины мер на социальную защиту и соџиальное обеспечение населения с иелью определения его эффективности в условиях ограниченных бюджетных ресурсов государства и необходимости обеспечения сочиальных гарантий для граждан. Проведено группирование стран-членов ЕС по приоритетности расходов на социальную защиту населения, сделано сравнение с соответствующими показателями в Украине. Рассчитана доля расходов на сочиальную защиту и социальное обеспечение сводного бюджета в ВВП Украиньl. Определена роль расходов на сочиальную защиту и соџиальное обеспечение в расходной части местных бюджетов Украины, рассмотрена их структура. Доказано, что финансирование сочиальньх расходов носит хаотический характер; какие-либо устоявшиеся тенденции по динамике удельного веса отдельных составляющих сочиальных расходов отсутствуют. Учитывая проведение в Украине реформы бюджетной децентрализации, исследовано разграничение бюджетного финансирования социальной защиты в разрезе государственного и местных бюджетов. Определено, что доля расходов на сочиильную защиту и сочиальное обеспечение в структуре местных бюджетов Украины высока, 
вместе с тем, на практике это не всегда обеспечивает надлежащий уровень качества предоставления сочиальных услуг населению. Обоснована потребность в разработке комплексного подхода $к$ реформированию бюджетного механизма реализации социальной функции государства на принцииах стабильности, прозрачности и взвешенного паритета интересов государства и общества.

Ключевые слова: сочиальная политика, бюджетное финансирование, местные бюджеты, социальные расходы, социальная защчита, социильное обеспечение.

L.P. SIDELNYKOVA

Kherson National Technical University ORCID: 0000-0001-7182-2923

\section{ASYMMETRY OF FINANCING OF LOCAL BUDGET EXPENDITURES ON SOCIAL PROTECTION AND SOCIAL SECURITY}

Budget financing of social protection and social security is one of the important factors of social development, which determines the standard of living and well-being of the poorest. The leading role of local budgets of Ukraine in the implementation of the social function of the state is determined by increasing the efficiency of the process of providing public services due to proximity to their immediate consumer. This process is based on the principle of subsidiarity, requires a sufficient level of financial security of local governments and demonstrates the basic idea of the concept of budget decentralization. The current practice of financing measures for social protection and social security of the population by local budgets of Ukraine is analyzed in the article in order to determine its effectiveness in conditions of limited budget resources of the state and the need to provide social guarantees for citizens. The grouping of EU member states according to the priority of expenditures on social protection of the population was conducted, a comparison with the corresponding indicators in Ukraine was made. The share of expenditures on social protection and social security of the consolidated budget in the GDP of Ukraine is calculated. The role of expenditures on social protection and social security in the expenditure part of local budgets of Ukraine is determined, their structure is considered. It is proved that the financing of social expenditures is chaotic; there are no steady trends in the dynamics of the share of individual components of social expenditures. In view of the reform of budget decentralization in Ukraine, the distinction between budget financing of social protection in the context of state and local budgets is studied. It is determined that the share of expenditures on social protection and social security in the structure of local budgets of Ukraine is high, however, in practice it does not always provide an adequate level of quality of social services to the population. The need to develop a comprehensive approach to reforming the budgetary mechanism for the implementation of the social function of the state on the principles of stability, transparency and balanced parity of interests of the state and society is substantiated.

Keywords: social policy, budget financing, local budgets, social expenditures, social protection, social security.

\section{Постановка проблеми}

Розбудова в Україні соціально-орієнтованої ринкової економіки передбачає стабільність і підтримання на безпечному рівні необхідних для існування соціуму параметрів, що відображені у системі соціальних стандартів рівня і якості життя населення. Разом з тим, посилення гібридних викликів, пов'язаних з веденням військових дій на Сході країни та анексією Автономної Республіки Крим; падіння обсягів виробництва та реалізації товарів, робіт, послуг внаслідок введення карантинних обмежень у зв'язку з поширенням пандемії COVID-19; стрімке зростання безробіття; значне підвищення тарифів на житлово-комунальні послуги; усунення держави від регулювання цін та інші негативні чинники зумовили масове зубожіння населення та загострили потребу в проведенні активної державної політики соціального захисту населення. Однією з ключових складових системи соціального захисту та соціального забезпечення громадян $\epsilon$ фінансування відповідних видатків 3 державного та місцевих бюджетів України. Зазначене актуалізує доцільність поглибленого вивчення проблематики і перспектив удосконалення фінансового забезпечення соціального захисту населення у нашій державі.

Аналіз останніх досліджень і публікацій

Дискусійні питання щодо доцільності державного фінансування соціальних потреб населення висвітлені у працях зарубіжних вчених: Дж. Бьюкенена, Т. Веблена, Т. Гоббса, Л. Ерхарда, Д. Коммонса, А. Маршалла, В. Ойкена, Дж. Ролза, В. Петті, Ж. Сісмонді, Дж. Стігліца, М. Фрідмена, Т. Шульца.

Питання оптимізації бюджетних видатків на соціальний захист та соціальне забезпечення досліджували і українські вчені, такі як: В. Булавинець, Л. Баластрик, О. Василик, В. Дем'янишин, М. Карлін, О. Кириленко, Л. Лисяк, В. Опарін, К. Павлюк, В. Тропіна, О. Тулай, В. Федосов, І. Чугунов.

Разом з тим, вітчизняні реалії нагромадження фінансових дисбалансів та концентрації фіскальних ризиків вимагають новітніх підходів до удосконалення бюджетного фінансування соціального захисту та соціальне забезпечення населення України.

Формулювання мети дослідження 
Метою статті є аналіз чинної практики фінансування місцевими бюджетами України заходів на соціальний захист та соціальне забезпечення населення з метою визначення його ефективності в умовах обмежених бюджетних ресурсів держави і необхідності забезпечення соціальних гарантій для громадян.

\section{Викладення основного матеріалу дослідження}

Бюджетне фінансування соціального захисту та соціального забезпечення $є$ одним з важливих чинників суспільного розвитку, який визначає рівень життя населення й добробут найменш забезпечених його верств. На сучасному етапі глобальних трансформаційних змін в більшості розвинутих країн світу панує соціально орієнтована ринкова економіка, яка регламентує захищеними статтями бюджетних видатків переважно видатки соціального спрямування. Оптимізація і перманентне зростання цих видатків $\epsilon$ пріоритетною політикою і нашої країни, що вказує на поступове посилення соціальної функції держави. Разом 3 тим, збільшення обсягів бюджетного фінансування соціального захисту та соціального забезпечення в Україні не супроводжується адекватними темпами зростання добробуту населення, не спонукає громадян до пошуку шляхів вирішення кризової ситуації, в якій вони опинилися, а лише тимчасово підтримує їхнє матеріальне становище, породжуючи при цьому утриманські настрої у суспільстві. Зазначене є наслідком обмежених фінансових можливостей держави та органів місцевого самоврядування, коли при збільшенні номінальних показників бюджетного фінансування соціального захисту та соціального забезпечення перманентно зростаюча інфляція знецінює спроможність держави забезпечити суспільний добробут шляхом надання соціальної допомоги та соціальних послуг.

Зважаючи на складне соціально-економічне становище України, пов'язане 3 веденням військових дій, необхідністю соціальної підтримки значної кількості внутрішньо переміщених осіб, зниження рівня добробуту громадян, зростання бюджетного дефіциту, а відтак і державного боргу, необхідності його обслуговування, фінансування соціального захисту населення стає все більш обтяжливим для держави.

Водночас, як зазначає А. Огінська, стратегічною метою в розвинутих країнах світу проголошено зростання ефективності соціальних видатків. При цьому важливим моментом є перенесення акценту 3 нарощування державних інвестицій в соціальну сферу на раціоналізацію їх використання [1, с. 28].

В таблиці 1 на підставі розрахованих показників частки видатків на соціальний захист населення у ВВП проведено групування країн-членів СС за моделлю пріоритетності соціального захисту.

Групування країн-членів Свропейського Союзу

Таблиця 1 за пріоритетністю видатків на соціальний захист населення *

\begin{tabular}{|c|c|}
\hline $\begin{array}{c}\text { Частка видатків } \\
\text { на соціальний захист у ВВП, \% }\end{array}$ & Країни-члени СС \\
\hline До 20\% ВВП & $\begin{array}{l}\text { Румунія (14,3\%), Латвія (14,6\%), Литва }(14,8 \%) \text {, Ірландія }(15,2 \%) \text {, Естонія } \\
(16,2 \%), \text { Болгарія }(17,3 \%) \text {, Мальта }(17,3 \%) \text {, Словаччина }(17,7 \%) \text {, Чехія }(18,4 \%), \\
\text { Угорщина }(19,7 \%) \text {. }\end{array}$ \\
\hline Від 20\% до 26\% ВВП & $\begin{array}{l}\text { Хорватія (20,7\%), Кіпр (21,4\%), Люксембург }(21,7 \%) \text {, Словенія }(23,4 \%) \text {, Іспанія } \\
(24,2 \%), \text { Португалія }(24,7 \%) \text {. }\end{array}$ \\
\hline Від 26\% до 35\% ВВП & $\begin{array}{l}\text { Греція (26,1\%), Німеччина (27,9\%), Велика Британія }(28,4 \%) \text {, Нідерланди } \\
(28,4 \%), \text { Швеція }(28,6 \%) \text {, Італія }(28,8 \%), \text { Австрія }(29,0 \%), \text { Бельгія }(29,1 \%), \\
\text { Данія }(31,1 \%) \text {, Фінляндія }(31,1 \%), \text { Франція }(32,0 \%) .\end{array}$ \\
\hline
\end{tabular}

Так, найменшу частку видатків на соціальний захист у структурі ВВП спрямовують країни постсоціалістичного табору (Румунія, Латвія, Литва, Естонія, Болгарія, Словаччина, Чехія, Угорщина). У цих країнах тривають реформи у напрямі забезпечення зростання економічного розвитку i переформатування джерел фінансування соціального захисту частково з центрального бюджету на фонди соціального страхування та благодійні організації.

До групи країн з найвищою часткою видатків на соціальний захист у структурі ВВП (від $26 \%$ до $35 \%$ ) традиційно належать країни Скандинавського півострова (Фінляндія, Швеція), а також високорозвинуті країни СС: Бельгія, Німеччина, Франція тощо.

Зазначимо, що джерелом фінансування соціальних видатків у європейських країнах є державний та місцеві бюджети, фонди соціального страхування, кошти благодійних організацій тощо. Перші два джерела фінансових ресурсів забезпечують більш як 95\% усіх видатків на соціальний захист населення, проте, у різних країнах співвідношення між ними різняться [1, с. 29].

Державна служба статистики України розраховує загальні видатки на соціальний захист за методологією європейської системи інтегрованої статистики соціального захисту. Використання єдиних методологічних підходів до побудови рахунку соціального захисту уможливлює співставність видатків на соціальний захист країн Євросоюзу та України. Соціальні витрати, представлені як частка ВВП, є визнаним критерієм, що характеризує ступінь державної відповідальності по підтримці певного стандарту життя найбідніших верств населення. 
Показник, обчислений за європейською методологією, у 2018 році становив 17,4\%; у 2019 році $17,2 \%$ [3, с. 11]. Отже, за часткою загальних видатків на соціальний захист та соціальне забезпечення у ВВП Україну цілком доречно можна віднести до групи країн постсоціалістичного табору.

В таблиці 2 розрахуємо частку видатків зведеного бюджету на соціальний захист та соціальне забезпечення у ВВП України.

Таблиця 2

Частка бюджетних видатків на соціальний захист та соціальне забезпечення у ВВП України у 2018-2020 роках *

\begin{tabular}{|l|c|c|c|}
\hline \multicolumn{1}{|c|}{ Показники } & 2018 рік & 2019 рік & 2020 рік \\
\hline $\begin{array}{l}\text { Видатки Державного бюджету України } \\
\text { на соціальний захист та соціальне забезпечення, млн. грн. }\end{array}$ & 163865,6 & 218628,6 & 322720,9 \\
\hline $\begin{array}{l}\text { Видатки місцевих бюджетів України } \\
\text { на соціальний захист та соціальне забезпечення, млн. грн. }\end{array}$ & 145498,0 & 103158,2 & 23999,6 \\
\hline $\begin{array}{l}\text { Разом видатків } \\
\text { на соціальний захист та соціальне забезпечення, млн. грн. }\end{array}$ & 309363,6 & 321786,8 & 346720,5 \\
\hline Валовий внутрішній продукт, млн. грн. & 3558706 & 3974564 & 4194102 \\
\hline $\begin{array}{l}\text { Частка видатків Зведеного бюджету України на соціальний } \\
\text { захист та соціальне забезпечення у ВВП, \% }\end{array}$ & 8,69 & 8,10 & 8,27 \\
\hline
\end{tabular}

* Примітка. Складено автором за даними джерел [4; 5].

Як свідчать дані, наведені в таблиці 2, частка видатків Зведеного бюджету України на соціальний захист та соціальне забезпечення у ВВП коливається в межах 8-9\%. Це є доволі високим показником, який відповідає рівню таких високорозвинених країн Свропи, як Ірландія, Ісландія, Фінляндія (середній зазначений показник в ЄС дорівнює 6\%). Отже, можемо зробити висновки про значну соціальну спрямованість бюджетної політики України.

Ключова роль у фінансуванні соціальної сфери в Україні відведена місцевим бюджетам. Саме бюджетні ресурси органів місцевого самоврядування забезпечують реалізацію низки програм та заходів соціального захисту населення, спрямованих на приведення рівня життя вразливих верств населення до соціальних стандартів, їх матеріальної підтримки у складних життєвих ситуаціях. Так, місцеві бюджети забезпечують фінансування соціальних трансфертів малозабезпеченим сім'ям, сім'ям з дітьми, інвалідам, ветеранам війни і праці та іншим категоріям громадян. Вони являють собою вагоме джерело їхніх доходів, нерідко дають змогу забезпечити придбання благ і послуг, необхідних для фізіологічного виживання осіб, які опинилися в складних життєвих обставинах. Саме завдяки видаткам місцевих бюджетів соціального спрямування забезпечується соціальний захист вразливих верств населення, зниження рівня майнового розшарування та бідності, соціальної напруги у суспільстві.

В таблиці 3 розглянемо розподіл акумульованих бюджетних ресурсів органів місцевого самоврядування між напрямами витрачання бюджетних коштів, згідно з функціональною класифікацією бюджетних видатків, і визначимо роль видатків на соціальний захист та соціальне забезпечення в структурі видаткової частини місцевих бюджетів України у 2018-2020 роках.

Таблиця 3

Структура видаткової частини місцевих бюджетів України у 2018-2020 роках *

\begin{tabular}{|l|c|c|c|c|c|c|}
\hline \multirow{2}{*}{ Показники } & \multicolumn{2}{|c|}{2018 рік } & \multicolumn{2}{c|}{2019 рік } & \multicolumn{2}{c|}{2020 рік } \\
\cline { 2 - 7 } & $\begin{array}{c}\text { сума, } \\
\text { млн. грн. }\end{array}$ & $\begin{array}{c}\text { питома } \\
\text { вага, } \%\end{array}$ & $\begin{array}{c}\text { сума, } \\
\text { млн. грн. }\end{array}$ & $\begin{array}{c}\text { питома } \\
\text { вага, \% }\end{array}$ & $\begin{array}{c}\text { сума, } \\
\text { млн. грн. }\end{array}$ & $\begin{array}{c}\text { питома } \\
\text { вага, \% }\end{array}$ \\
\hline Загальнодержавні функціі & 28591,9 & 5,08 & 34914,8 & 6,26 & 40969,4 & 8,76 \\
\hline $\begin{array}{l}\text { Громадський порядок, безпека та } \\
\text { судова влада }\end{array}$ & 1149,6 & 0,20 & 1304,6 & 0,23 & 1833,8 & 0,39 \\
\hline Економічна діяльність & 77160,5 & 13,70 & 81854,2 & 14,68 & 93926,6 & 20,09 \\
\hline $\begin{array}{l}\text { Охорона навколишнього } \\
\text { природного середовища }\end{array}$ & 3000,9 & 0,53 & 3413,5 & 0,61 & 2419,8 & 0,52 \\
\hline $\begin{array}{l}\text { Житлово-комунальне } \\
\text { господарство }\end{array}$ & 30048,6 & 5,33 & 34382,0 & 6,17 & 32126,0 & 6,87 \\
\hline Охорона здоров'я & 93233,9 & 16,55 & 89818,0 & 16,11 & 50866,0 & 10,88 \\
\hline Духовний та фізичний розвиток & 18886,0 & 3,35 & 21583,2 & 3,87 & 21884,5 & 4,68 \\
\hline Освіта & 165708,0 & 29,42 & 187102,1 & 33,56 & 199425,9 & 42,66 \\
\hline $\begin{array}{l}\text { Соціальний захист та соціальне } \\
\text { забезпечення }\end{array}$ & 145498,0 & 25,83 & 103158,2 & 18,50 & 23999,6 & 5,13 \\
\hline $\begin{array}{l}\text { Разом видатків (без урахуван-ня } \\
\text { міжбюджетних трансфертів) }\end{array}$ & 563277,4 & 100,00 & 557530,6 & 100,00 & 467451,6 & 100,00 \\
\hline
\end{tabular}

* Примітка. Складено автором за даними джерел [4]. 
Як свідчать дані, наведені в таблиці 3, ключовим пріоритетом витрачання бюджетних ресурсів органів місцевого самоврядування є фінансування сфери освіти, причому протягом 2018-2020 років питома вага видатків на освіту перманентно зростала: 29,42\%; 33,56\%; 42,66\% відповідно.

Щороку впродовж 2018-2020 років зростала і частка видатків місцевих бюджетів України на духовний та фізичний розвиток: $3,35 \% ; 3,87 \% ; 4,68 \%$ відповідно.

Разом 3 тим, протягом 2018-2020 років значно скоротилися номінальні обсяги фінансування видатків на охорону здоров'я і соціальний захист та соціальне забезпечення, що спричинило поступове зниження їхньої питомої ваги у загальному обсязі видаткової частини місцевих бюджетів України (16,55\%; 16,11\%; 10,88\% та 25,83\%; 18,50\%; 5,13\% відповідно).

Вищезазначене засвідчує пріоритетне значення видатків соціального спрямування (охорона здоров'я, духовний та фізичний розвиток, освіта, соціальний захист та соціальне забезпечення) у місцевих бюджетах України у 2018-2020 роках, адже їхня сумарна частка, хоча і поступово скорочувалася, однак була в цей період визначальною: 75,15\%; 72,04\%; 63,35\% відповідно.

Отже, провідна роль місцевих бюджетів України у реалізації соціальної функції держави обумовлена підвищенням ефективності процесу надання суспільних послуг завдяки наближеності до їх безпосереднього споживача. Цей процес базується на принципі субсидіарності, потребує достатнього рівня фінансової забезпеченості органів місцевого самоврядування і демонструє основну ідею концепції бюджетної децентралізації. Разом $з$ тим, характерною особливістю вітчизняної практики бюджетного фінансування в цілому та видатків на соціальний захист та соціальне забезпечення зокрема $є$ значний ступінь нестабільності обсягів бюджетних асигнувань у розрізі напрямів витрачання коштів. Звісно, частково така волатильність є об’єктивною, однак нерідко високі показники мінливості видатків пояснюються непослідовністю у фінансуванні важливих бюджетних, у тому числі соціальних, програм.

В таблиці 4 розглянемо структуру видатків на соціальний захист та соціальне забезпечення місцевих бюджетів України у 2018-2020 роках.

Таблиця 4

Структура видатків на соціальний захист та соціальне забезпечення місцевих бюджетів України у 2018-2020 роках *

\begin{tabular}{|l|c|c|c|c|c|c|}
\hline \multirow{2}{*}{ Показники } & \multicolumn{2}{|c|}{2018 рік } & \multicolumn{2}{c|}{2019 рік } & \multicolumn{2}{c|}{2020 рік } \\
\cline { 2 - 7 } & $\begin{array}{c}\text { сума, } \\
\text { млн. грн. }\end{array}$ & $\begin{array}{c}\text { питома } \\
\text { вага, \% }\end{array}$ & $\begin{array}{c}\text { сума, } \\
\text { млн. грн. }\end{array}$ & $\begin{array}{c}\text { питома } \\
\text { вага, \% }\end{array}$ & $\begin{array}{c}\text { сума, } \\
\text { млн. грн. }\end{array}$ & $\begin{array}{c}\text { питома } \\
\text { вага, \% }\end{array}$ \\
\hline $\begin{array}{l}\text { Соціальний захист на випадок } \\
\text { непрацездатності }\end{array}$ & 14377,5 & 9,88 & 15968,5 & 15,48 & 1490,3 & 6,21 \\
\hline Соціальний захист пенсіонерів & 7849,7 & 5,40 & 8957,1 & 8,68 & 10048,5 & 41,87 \\
\hline $\begin{array}{l}\text { Соціальний захист ветеранів } \\
\text { війни та праці }\end{array}$ & 8815,6 & 6,06 & 8431,1 & 8,17 & 634,8 & 2,65 \\
\hline $\begin{array}{l}\text { Соціальний захист сім'ї, дітей та } \\
\text { молоді }\end{array}$ & 41771,8 & 28,71 & 43954,9 & 42,61 & 2098,8 & 8,75 \\
\hline Соціальний захист безробітних & 150,9 & 0,10 & 186,0 & 0,18 & 93,0 & 0,39 \\
\hline $\begin{array}{l}\text { Допомога у вирішенні } \\
\text { житлового питання }\end{array}$ & 65402,5 & 44,95 & 16345,3 & 15,84 & 792,0 & 3,30 \\
\hline $\begin{array}{l}\text { Соціальний захист інших } \\
\text { категорій населення }\end{array}$ & 3014,2 & 2,07 & 3973,4 & 3,85 & 2788,4 & 11,62 \\
\hline $\begin{array}{l}\text { Інша діяльність у сфері } \\
\text { соціального захисту }\end{array}$ & 4115,8 & 2,83 & 5341,9 & 5,18 & 6053,8 & 25,22 \\
\hline $\begin{array}{l}\text { Разом видатків на соціальний } \\
\text { захист та соціальне забезпечення }\end{array}$ & 145498,0 & 100,00 & 103158,2 & 100,00 & 23999,6 & 100,00 \\
\hline
\end{tabular}

* Примітка. Складено автором за даними джерел [4].

Як свідчать дані, наведені в таблиці 4, фінансування видатків на соціальний захист та соціальне забезпечення місцевими бюджетами України має хаотичний характер; будь-які сталі тенденції щодо динаміки питомої ваги окремих складових соціальних видатків відсутні.

Так, у 2018 році ключовим пріоритетом витрачання коштів місцевих бюджетів, передбачених на фінансування видатків на соціальний захист та соціальне забезпечення, була допомога у вирішенні житлового питання. Питома вага цієї складової соціальних видатків у загальному обсязі соціальних видатків місцевих бюджетів України становила 44,95\%. Разом 3 тим, у наступних роках спостерігається стрімке скорочення частки цієї складової соціальних видатків: 2019 рік - 15,84\%; 2020 рік - 3,30\%.

Протилежна ситуація спостерігається щодо видатків на соціальний захист пенсіонерів: у 2018 році їхня частка у загальному обсязі видатків місцевих бюджетів на соціальний захист та соціальне забезпечення була незначною - 5,40\%; у 2019 році - підвищилася до 8,68\%; у 2020 році - стрімко підскочила до 41,87\%. 
Доволі вагомою у 2018-2019 роках була частка видатків на соціальний захист сім’і, дітей та молоді: 28,71\% та 42,61\% відповідно. Разом 3 тим, питома вага зазначеної складової видатків на соціальний захист та соціальне забезпечення у 2020 році дуже істотно зменшилася і склала $8,75 \%$.

Сталу тенденцію до зростання з доволі значною часткою у 2020 році демонструє інша діяльність у сфері соціального захисту: 2018 рік - 2,83\%; 2019 рік - 5,18\%; 2020 рік - 25,22\%. Тобто у 2020 році ця складова соціальних видатків становила чверть загального обсягу видатків місцевих бюджетів на соціальний захист та соціальне забезпечення.

Значна увага органами місцевого самоврядування приділяється фінансуванню соціального захисту на випадок непрацездатності; разом з тим, будь-які тенденції у зміні питомої ваги цієї складової соціальних видатків у загальному обсязі видатків місцевих бюджетів на соціальний захист та соціальне забезпечення відсутні: 2018 рік - 9,88\%; 2019 рік - 15,48\%; 2020 рік - 6,21\%.

Не прослідковується жодних тенденцій у зміні частки у загальному обсязі видатків місцевих бюджетів на соціальний захист і соціальне забезпечення і щодо видатків на соціальний захист ветеранів війни та праці. Питома вага цієї складової соціальних видатків складала у 2018 році 6,06\%; у 2019 році $8,17 \%$; у 2020 році - $2,65 \%$.

Натомість, видатки на соціальний захист інших категорій населення демонструють сталу тенденцію до зростання: 2018 рік - 2,07\%; 2019 рік - 3,85\%; 2020 рік - 11,62\% загального обсягу видатків місцевих бюджетів на соціальний захист та соціальне забезпечення.

Найменшою складовою цієї категорії видатків місцевих бюджетів є видатки на соціальний захист безробітних, питома вага яких, хоча і поступово збільшується, але залишається мізерною: 2018 рік - 0,10\%; 2019 рік - 0,18\%; 2020 рік - 0,39\%.

Зважаючи на проведення в Україні реформи бюджетної децентралізації, вважаємо за доцільне більш детально звернути увагу на розмежування бюджетного фінансування соціального захисту у розрізі державного та місцевих бюджетів (табл. 5).

Видатки на соціальний захист та соціальне забезпечення в Україні

Таблиця 5 у розрізі державного та місцевих бюджетів у 2018-2020 роках *

\begin{tabular}{|c|c|c|c|c|c|c|}
\hline \multirow{2}{*}{ Показники } & \multicolumn{2}{|c|}{2018 рік } & \multicolumn{2}{|c|}{2019 рік } & \multicolumn{2}{|c|}{2020 рік } \\
\hline & $\begin{array}{c}\text { сума, } \\
\text { млн. грн. }\end{array}$ & $\begin{array}{l}\text { питома } \\
\text { вага,\% }\end{array}$ & $\begin{array}{c}\text { сума, } \\
\text { млн. грн. }\end{array}$ & $\begin{array}{c}\text { питома } \\
\text { вага,\% }\end{array}$ & $\begin{array}{c}\text { сума, } \\
\text { млн. грн. }\end{array}$ & $\begin{array}{c}\text { питома } \\
\text { вага,\% } \\
\end{array}$ \\
\hline \multicolumn{7}{|c|}{ Соціальний захист на випадок непрацездатності } \\
\hline Державний бюджет & 1731,1 & 10,75 & 2740,9 & 14,65 & 2555,3 & 63,16 \\
\hline Місцеві бюджети & 14377,5 & 89,25 & 15968,5 & 85,35 & 1490,3 & 36,84 \\
\hline \multicolumn{7}{|c|}{ Соціальний захист пенсіонерів } \\
\hline Державний бюджет & 150091,0 & 95,03 & 182270,1 & 95,32 & 202280,4 & 95,27 \\
\hline Місцеві бюджети & 7849,7 & 4,97 & 8957,1 & 4,68 & 10048,5 & 4,73 \\
\hline \multicolumn{7}{|c|}{ Соціальний захист ветеранів війни та праці } \\
\hline Державний бюджет & 1418,8 & 13,86 & 1444,7 & 14,63 & 1607,8 & 71,69 \\
\hline Місцеві бюджети & 8815,6 & 86,14 & 8431,1 & 85,37 & 634,8 & 28,31 \\
\hline \multicolumn{7}{|c|}{ Соціальний захист сім'ї, дітей та молоді } \\
\hline Державний бюджет & 113,1 & 0,27 & 136,6 & 0,31 & 78,6 & 3,61 \\
\hline Місцеві бюджети & 41771,8 & 99,73 & 43954,9 & 99,69 & 2098,8 & 96,39 \\
\hline \multicolumn{7}{|c|}{ Соціальний захист безробітних } \\
\hline Державний бюджет & 0,0 & 0,00 & 0,0 & 0,00 & 6646,3 & 98,62 \\
\hline Місцеві бюджети & 150,9 & 100,00 & 186,0 & 100,00 & 93,0 & 1,38 \\
\hline \multicolumn{7}{|c|}{ Допомога у вирішенні житлового питання } \\
\hline Державний бюджет & 3830,5 & 5,53 & 25548,3 & 60,98 & 38614,9 & 97,99 \\
\hline Місцеві бюджети & 65402,5 & 94,47 & 16345,3 & 39,02 & 792,0 & 2,01 \\
\hline \multicolumn{7}{|c|}{ Соціальний захист інших категорій населення } \\
\hline Державний бюджет & 6233,3 & 67,41 & 6221,4 & 61,03 & 70709,8 & 96,21 \\
\hline Місцеві бюджети & 3014,2 & 32,59 & 3973,4 & 38,97 & 2788,4 & 3,79 \\
\hline \multicolumn{7}{|c|}{ Фундаментальні та прикладні дослідження і розробки у сфері соціального захисту } \\
\hline Державний бюджет & 31,6 & 100,00 & 30,5 & 100,00 & 28,0 & 100,00 \\
\hline Місцеві бюджети & 0,0 & 0,00 & 0,0 & 0,00 & 0,0 & 0,00 \\
\hline \multicolumn{7}{|c|}{ Інша діяльність у сфері соціального захисту } \\
\hline Державний бюджет & 416,3 & 9,19 & 235,9 & 4,23 & 199,9 & 3,20 \\
\hline Місцеві бюджети & 4115,8 & 90,81 & 5341,9 & 95,77 & 6053,8 & 96,80 \\
\hline
\end{tabular}




\begin{tabular}{|l|c|c|c|c|c|c|}
\hline \multicolumn{7}{|c|}{ Разом видатків на соціальний захист та соціальне забезпечення } \\
\hline Державний бюджет & 163865,6 & 52,97 & 218628,6 & 67,94 & 322720,9 & 93,08 \\
\hline Місцеві бюджети & 145498,0 & 47,03 & 103158,2 & 32,06 & 23999,6 & 6,92 \\
\hline
\end{tabular}

Як свідчать дані, наведені в таблиці 5, протягом 2018-2020 років переважна частина видатків на соціальний захист та соціальне забезпечення фінансувалася за рахунок коштів державного бюджету, причому питома вага державного бюджету у загальному обсязі фінансування соціальних видатків поступово зростала, досягнув домінантного значення у 2020 році: 2018 рік - 52,97\%; 2019 рік - 67,94\%; 2020 рік - 93,08\%. Відповідно, частка соціальних видатків, профінансованих з місцевих бюджетів, поступово скорочувалася, досягнув у 2020 році мінімального значення: 2018 рік - 47,03\%; 2019 рік $32,06 \% ; 2020$ рік - 6,92\%.

У розрізі складових видатків зведеного бюджету на соціальний захист та соціальне забезпечення розподіл фінансування між державним та місцевими бюджетами у 2018-2020 роках є таким:

- видатки на соціальний захист на випадок непрацездатності у 2018-2019 роках у переважному обсязі фінансувалися за рахунок коштів місцевих бюджетів: 89,25\% та 85,35\% відповідно; натомість, у 2020 році ситуація змінилася і зазначені видатки були профінансовані з місцевих бюджетів лише на $36,84 \%$. Питома вага державного бюджету у фінансуванні видатків на соціальний захист на випадок непрацездатності у 2018-2020 роках становила 10,75\%; 14,65\%; 63,16\% відповідно;

- видатки на соціальний захист пенсіонерів традиційно майже повністю фінансуються за рахунок коштів державного бюджету, питома вага якого протягом 2018-2020 років становила 95,03\%; 95,32\%; 95,27\% відповідно. В свою чергу, частка місцевих бюджетів у фінансуванні цього виду соціальних видатків була незначною: 2018 рік - 4,97\%; 2019 рік - 4,68\%; 2020 рік - 4,73\%;

- видатки на соціальний захист ветеранів війни та праці у 2018-2019 роках у переважному обсязі фінансувалися за рахунок коштів місцевих бюджетів: 86,14\% та 85,37\% відповідно; натомість, у 2020 році ситуація змінилася, і зазначені видатки були профінансовані з місцевих бюджетів лише на 28,31\%. Питома вага державного бюджету у фінансуванні видатків на соціальний захист ветеранів війни та праці у 2018-2020 роках становила $13,86 \% ; 14,63 \% ; 71,69 \%$ відповідно;

- видатки на соціальний захист сім'ї, дітей та молоді майже повністю фінансуються за рахунок місцевих бюджетів (2018 рік - 99,73\%; 2019 рік - 99,69\%; 2020 рік - 96,39\% загального обсягу профінансованих заходів цього напряму). Відповідно, частка коштів, спрямованих на соціальний захист сім’ї, дітей та молоді з державного бюджету, є мізерною: 2018 рік - 0,27\%; 2019 рік - 0,31\%; 2020 рік $3,61 \%$;

- видатки на соціальний захист безробітних у 2018-2019 роках в повному обсязі фінансувалися за рахунок коштів місцевих бюджетів; однак у 2020 році ситуація кардинально змінилися: 98,62\% цих видатків було профінансовано з державного бюджету і лише 1,38\% - з місцевих бюджетів України;

- кардинальну зміну підходів спостерігаємо і щодо фінансування допомоги у вирішенні житлового питання. Якщо у 2018 році ключова роль у ії забезпеченні належала місцевим бюджетам (94,47\%), то у 2020 році - державному бюджету (97,99\%). В цілому, розподіл фінансування зазначеного виду соціальних видатків між рівнями бюджетної системи має такий вигляд: державний бюджет: 2018 рік - 5,53\%; 2019 рік - 60,98\%; 2020 рік - 97,99\%; місцеві бюджети: 2018 рік - 94,47\%; 2019 рік - 39,02\%; 2020 рік - 2,01\%;

- видатки на соціальний захист інших категорій населення у 2018-2019 роках переважно забезпечувалися за рахунок коштів державного бюджету, питома вага якого у загальних обсягах фінансування цього виду соціальних видатків складала 67,41\% та 61,03\% відповідно. У 2020 році частка державного бюджету стала домінантною - 96,21\%. Відповідно, питома вага місцевих бюджетів у фінансуванні видатків на соціальний захист інших категорій населення у 2018-2020 роках становила 32,59\%; 38,97\%; 3,79\% відповідно;

- видатки на фундаментальні та прикладні дослідження і розробки у сфері соціального захисту протягом аналізованого періоду повністю фінансувалися за рахунок коштів державного бюджету;

- видатки на іншу діяльність у сфері соціального захисту майже в повному обсязі фінансуються за рахунок місцевих бюджетів (2018 рік - 90,81\%; 2019 рік - 95,77\%; 2020 рік - 96,80\% загального обсягу профінансованих заходів цього напряму). Відповідно, частка коштів, спрямованих на іншу діяльність у сфері соціального захисту з державного бюджету, є незначною: 2018 рік - 9,19\%; 2019 рік - 4,23\%; 2020 рік - 3,20\%.

Підсумовуючи аналіз таблиці 4, можемо констатувати кардинальні зміни у підході до розподілу обсягів фінансування видатків на соціальний захист та соціальне забезпечення між державним та місцевими бюджетами у 2020 році.

\section{Висновки}

За результатами проведеного дослідження зазначимо, що частка видатків на соціальний захист 
та соціальне забезпечення в структурі місцевих бюджетів України є високою, разом з тим, на практиці це не завжди забезпечує належний рівень якості надання соціальних послуг населенню. Багаторічне гальмування реформ у соціальній сфері призводить до неефективного використання значної частки бюджетних асигнувань, виділених на соціальну підтримку громадян, які опинилися у складних життєвих обставинах.

Водночас, зауважимо, що перманентне зростання видатків на соціальний захист та соціальне забезпечення за рахунок бюджетних коштів продукує у населення споживацькі настрої та не спонукає його до забезпечення якісного рівня життя за рахунок власної праці. Зазначене підтверджує В. Булавинець, яка зазначає, що упродовж тривалого часу головний акцент робиться на підвищенні соціальних трансфертів, що неминуче руйнує мотивацію активної поведінки на ринку праці. Через це соціальні трансферти називають непродуктивними видатками [6, с. 302]. Необгрунтоване збільшення обсягів бюджетного фінансування соціальної підтримки малозабезпечених верств населення виявляється невиправданим, адже призводить до важких негативних наслідків у майбутньому, а саме: до формування сталої залежності певної категорії громадян від матеріальної державної допомоги. Перманентне зростання видатків місцевих бюджетів України на соціальний захист генерує більше негативних, ніж позитивних результатів, крім того, позитивні зміни від збільшення соціальної допомоги матимуть лише тимчасовий характер, а негативні - довгостроковий. Як результат, незважаючи на щорічне зростання обсягів і темпів бюджетного фінансування соціального захисту та соціального забезпечення, позитивних змін у якості життя більшої частини населення держави не спостерігається. Система соціальної допомоги населенню не відповідає потребам сьогодення. Це, насамперед, пов'язано з розпорошуванням коштів на виплату допомоги окремим групам населення без якісного урахування їх доходів, реального соціального стану тощо. Тому подальші дослідження у даному напрямі мають відбуватися у площині не лише аналітичних розрахунків та наукового обгрунтування рівня видатків на соціальний захист та соціальне забезпечення місцевих бюджетів, адекватного сучасним інституціональним умовам, а й передбачати комплексний підхід до реформування бюджетного механізму реалізації соціальної функції держави на принципах стабільності, прозорості та виваженого паритету інтересів держави і суспільства.

\section{Список використаної літератури}

1. Огінська А.Ю. Світові тенденції бюджетного фінансування соціального захисту населення та можливості їх використання в Україні. Економіка. Фінанси. Право. 2018. № 3/2. С. 26-31.

2. Національні рахунки соціального захисту (НРС3) в Україні у 2016 році : статистичний збірник. Київ : Державна служба статистики України, 2016. 94 с.

3. Соціальний захист населення України у 2020 році : статистичний збірник. Київ : Державна служба статистики України, 2021. 121 с.

4. Звіти Державної казначейської служби України про виконання бюджетів всіх рівнів за 2018-2020 роки. URL: https://www.treasury.gov.ua/ua/file-storage/vikonannya-derzhavnogo-byudzhetu (дата звернення: 01.10.2021).

5. Валовий внутрішній продукт України за 2018-2020 роки. URL: https://index.minfin.com.ua/economy/gdp/ (дата звернення: 01.10.2021).

6. Модернізація місцевих фінансів України в умовах економічних і соціальних трансформацій : монографія / під ред. О.П. Кириленко. Тернопіль: Економічна думка, 2008. 376 с.

\section{References}

1. Ohinska A.Iu. (2018) Svitovi tendentsii biudzhetnoho finansuvannia sotsialnoho zakhystu naselennia ta mozhlyvosti yikh vykorystannia $\mathrm{v}$ Ukraini [Global trends in budget financing of social protection and the possibility of their use in Ukraine]. Ekonomika. Finansy. Pravo, vol. 3/2, pp. 26-31.

2. Natsionalni rakhunky sotsialnoho zakhystu (NRSZ) v Ukraini u 2016 rotsi [National Social Protection Accounts (NSPA) in Ukraine in 2016]. Kyiv : Derzhavna sluzhba statystyky Ukrainy, 2016. 94 p.

3. Sotsialnyi zakhyst naselennia Ukrainy u 2020 rotsi [Social protection of the population of Ukraine in 2020]. Kyiv : Derzhavna sluzhba statystyky Ukrainy, 2021. 121 p.

4. Zvity Derzhavnoi kaznacheiskoi sluzhby Ukrainy pro vykonannia biudzhetiv vsikh rivniv za 2018-2020 roky. URL: https://www.treasury.gov.ua/ua/file-storage/vikonannya-derzhavnogo-byudzhetu. Accessed 01 Oct. 2021.

5. Valovyi vnutrishnii produkt Ukrainy za 2018-2020 roky. URL: https://index.minfin.com.ua/economy/gdp/. Accessed 01 Oct. 2021.

6. Kyrylenko O.P., etc. (2008) Modernizatsiia mistsevykh finansiv Ukrainy v umovakh ekonomichnykh i sotsialnykh transformatsii [Modernization of local finances of Ukraine in the conditions of economic and social transformations]. In O.P. Kyrylenko (Ed.). Ternopil: Ekonomichna dumka (in Ukrainian). 